\title{
SEAWEED AS MICRONUTRIENTS INGREDIENT FOR FOOD SUPPLEMENT
}

\author{
Fifi Retiaty 1)*, Ade Nugraheni1), Astuti Lamid ${ }^{2)}$ \\ 1)Centre of Biomedical and Basic Technology of Health, \\ 2) Centre of Applied Technology of Health and Clinical Epidimiology, \\ Percetakan Negara Street 29, Centre of Jakarta-Indonesia (1020) \\ *e-mail : fifihadi@ymail.com
}

\begin{abstract}
In some part of Indonesia seaweed has been used as vegetables dish. The most important component of seaweed isiodine and iron. Gracillariasp is one species of seaweed that can be used as a source of the mikronutrients such as iron, iodine and calcium. Iron Deficiency Anemia and lodine Deficiency Disorder can cause several diseases also known low haemoglobin level and iodine level in the blood. This preparation of Gracillariasp could supplement micronutrients in the diet. This study was to develop appropriate local technology of Gracillariaspcontainedas an ingredient in the making of food supplement for imorovement of micronutrients intake.The experimental study uses optimum formulated comosition from seaweed.Based on the practical in the area (Bali), the formula of seaweed compose of seaweed of Gracillaria with additional of $20 \%$ salty fish extract, $5 \%$ dextrin. The seaweeds contains high of carbohydrate, iodine, calcium and iron but low in protein and lipid. Appropriate technology of dried seaweed supplement could be prepared at home. Theseseaweed supplements could be advocated in rural arealevel or posyandufor combating under nutrition status of the children. The formula of direct seaweed inclusion inthe supplement is preferred due to green colour and acceptable taste compared to dried seaweed. The serving sice of $25 \mathrm{~g}$ of this product could be cover children's need about $23 \%$ in iodine, $100 \%$ in iron and $22-35 \%$ in calcium.
\end{abstract}

Keywords: seaweed, Gracillariasp, iodine, iron, food supplement

\section{INTRODUCTION}

Malnutrition is still cause of death of nearly half of the children in developing countries. The main nutrition problems areprotein energy malnutrition (PEM), vitamin A deficiency (VAD), iron deficiency anemia (IDA) and iodine deficiency disorder (IDD). The interaction of micronutrient deficiency is related to nutritional status due to metabolism of protein and energy less efficient and therefore clinical signs are detected. Micro nutrient include vitamin A, iron and iodine must be available in daily intake of food consumption to combat nutritional problems (Hidayati et al. 2010; NIHRD 2008).

It has been known that macro-algae isone of marine plant rich in pigment and also micronutrient content. In some part of Indonesia,especially Bali, seaweedsof gracillaria and caulerpa have been consumed as vegetable (salad of seaweed) made of Bulunghijau (Gracillariasp) and bulungbunih (cauoloflowers). Theseaweedof Glacilariaisgenerally known as producer of agarophyteasprimary metabolism and extraction of this seaweed in the conditionof acids or bases, marketed in various forms, for example, agar-agar powder, paper and aga- agar bars and processed into various forms of snacks (cake), pudding, jelly, and supplementary materials used in the pharmaceutical industry. Gelatin content is relatively high 
and consumed as a functional food. Through a certain process of gelatin also produced into media for use in the laboratory as a medium for bacterial culture or tissue culture (Komari et al. 1997; Rasyid 2004).

Bulunghijau (Gracillariasp) is one species of seaweed that can be used as source of the mineral include iodine, iron and carotene. Carotene had been used as vitamin A sources supplemented into noodle, since carotene can be converted becomes vitamin A (Retinol).lodine and iron are the most important component of seaweedcould be used as food supplements for improve intake of Iron and iodine.

Present nutrition intervention inform of supplementswere iron, iodine and vitamin $A$ capsules in high doses to improve nutritional status of the target subjects given for 6 moths or 2 years. In treditional tehnology, the empowerment of people to use traditional seaweed for micronutrientintake can be formulated into daily food consumed by terget subjects. This food enriched with micronutrient would be beneficial for appropiate technology of community in house fortification.

The role of community is important for successful of this program. Community may have active role in improving nutrient intake of the family by program in house fortification such as micronutrient fortification in main dishes during consumption. The localtechnology must be rich in micronutrients content and also ease to prepared and improve stored time (Lamid et al. 1999).

The product available at the present was in form of sheet or dried product with specific taste. In Indonesia such as Bali, seaweed is consumedwith salted fishy taste as snack or to be eaten side dishes of rice (Dawezsky et al. 2007). Bulung hijau (Gracilaria sp) used in this study can be prepared into food supplement or formula of fortification of micro nutrient. This product must be dried so that can be distributed whole year, and keep the micronutrient available in high concentration by formulated with dextrin. The formula is developed into thin sheet or dried granule that soft and eatable as side dishes.

\section{MATERIALS AND METHODS}

\section{Materials}

The materials that used in this research were :Bulunghijau(Gracillariasp)were collected from Bali. Salty fish extract that used in this research was collected from the craftsman maker boiled fish at Bogor-Indonesia, and Dextrin Powder as fillers.

\section{Methods}

2.1 Seaweed supplement preparation

Formulation of seaweeds into nutrient supplementsfor fortification in house hold level besed on dried powder. The seaweed of Bulunghijau (Gracilariasp) were taken from Bali with salty fish extract and this special taste would be considered into product development. First, bulunghijau (Gracillariasp) werethoroughly cleaned with running water to remove foreign materials such as epiphytes, sands, and shells. Then the seaweed was cleaned with boiling 
water to removes particles or mucous attaching in the surface of the leaves. There were two seaweed formulations in this study:

a. The cleaned seaweeds was blended until obtained a very small particle and mixed with $10 \%$ dextrin $(\mathrm{w} / \mathrm{w})$ and $20 \%(\mathrm{w} / \mathrm{v})$ salty fish extract. Then the mixture was mixed well and dried with oven at $60^{\circ} \mathrm{C}$ temperature until dry completely.

b. The cleaned seaweeds was blended until obtained a very small particle, then it was dried and mixed with $10 \%(w / w)$ dextrin and $20 \%(w / v)$ salty fish extract. Then it was stirred well and dried with oven at $60^{\circ} \mathrm{C}$ temperature, until dry completely.

\subsection{Proximate analysis}

The proximate chemical composition (protein, carbohydrate, crude lipid, fiber, ash and moisture content) of the seaweed was determined according to the ASEAN Food standard method. Protein content was analyzed by the Kjeldahl method. A conversion factor of 6.25 has been used to convert total nitrogen content into crude protein. Carbohydrate content was determined as the weight difference using crude protein, lipid, fibre, moisture and ash content data. Crude lipid of the seaweed was extracted from seaweed powder in a Soxhlet extractor with petroleum ether. After ensuring complete extraction of crude lipid, petroleum ether was evaporated and the residue was dried to a constant weight at $105^{\circ} \mathrm{C}$. To determine the fibre content of seaweed $2 \mathrm{~g}$ samples were boiled with diluted $\mathrm{H}_{2} \mathrm{SO}_{4}(0.3 \mathrm{~N})$. Then the mixture of sample and $\mathrm{H}_{2} \mathrm{SO}_{4}$ was filtered and washed with $200 \mathrm{ml}$ boiling distilled water and $\mathrm{NaOH}$ $(0.5 \mathrm{~N})$. After washing by boiling distilled water and acetone the residue was re-extracted and dried at $105^{\circ} \mathrm{C}$ to constant weight. The moisture content was determined by drying the seaweed samples in an oven at $120^{\circ} \mathrm{C}$ until a constant weight was obtained and the ash content was estimated by heating the seaweeds in a muffle furnace at $550^{\circ} \mathrm{C}$ for $4 \mathrm{~h}$ (ASEAN FOODS 2011).

\subsection{Minerals Analysis}

The minerals $(\mathrm{Ca}, \mathrm{Fe}$ and $\mathrm{Na})$ content of samples was analyzed by atomic absorption spectrophotometer (AAS), except iodine used spectrophotometer.

2.4 Calcium, Iron, Sodium detetmined using AAS:

a. Calcium Analysis Procedure :

Samples were prepared by dry ashing and the mineral was diluted in Nitrica acid $1 \mathrm{~N}$

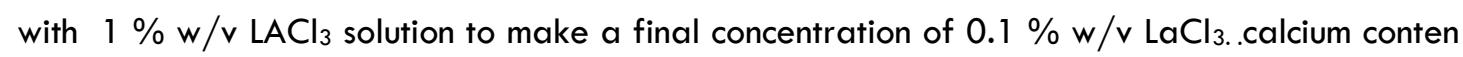
was measured by injection to AAS with wavelength $422.7 \mathrm{~nm}$. The content could be calculated with the standar

b. Iron Analysis Procedure :

The iron from dry ash was diluted with Nitric Acid 1 intto $100 \mathrm{ml}$. The aliquot was read at AAS with wavelength $248.3 \mathrm{~nm}$. 
c. Sodium Analysis Procedure :

The ash of sample was diluted with Nitric acid $1 \mathrm{~N}$ and add $\mathrm{CsCl}_{2}$ solution to an aliquot portion to make a final dilution of $1 \% \mathrm{w} / \mathrm{v} \mathrm{CsCl}_{2}$ prior to the analysis. The aliquot was then determinattto AAS with wavelength 330,4 nm (ASEAN FOODS 2011)

\section{5 lodine determination used spectrophotometer:}

Sample was taken for 2 gram in crucible and digested with $2 \mathrm{ml}$ solution of $\mathrm{NaOH} 2 \%$ and $\mathrm{KNO}_{3} 1 \%$ in $105^{\circ} \mathrm{C}$ for 24 hours and then another wet ashes in muffle. The ashes was then diluted in $50 \mathrm{ml}$. Sample was taken $3 \mathrm{ml}$ and added with arsenic acid $2 \mathrm{ml}$ and allow for 15 minutes and color development is after added with $1 \mathrm{ml} \mathrm{Ce}\left(\mathrm{SO}_{4}\right) \cdot 4 \mathrm{H}_{2} \mathrm{O}$ and its absorbance was measured at $415 \mathrm{~nm}$. The calculation was using calibration standard on iodine $100 \mathrm{ppm}$ using the same solution as sample (ASEAN FOODS 2011).

\section{RESULTS AND DISCUSSION}

Raw seaweed was green and having fishy odour. The chemical composition of the productcan be shown in Table 1 and Table 2. Table 1 showed that raw seaweed content of high carbohydrate and micro nutrient but low in protein and lipid content. This seaweeds Gracillariasp contains $162 \mathrm{Kcal}$ energy, very low protein $(0,8 \mathrm{~g} / 100 \mathrm{~g})$, lipid $(0,5 \mathrm{~g} / 100 \mathrm{~g})$, and high in micro minerals such as Calcium, iron and iodine (Table 1)

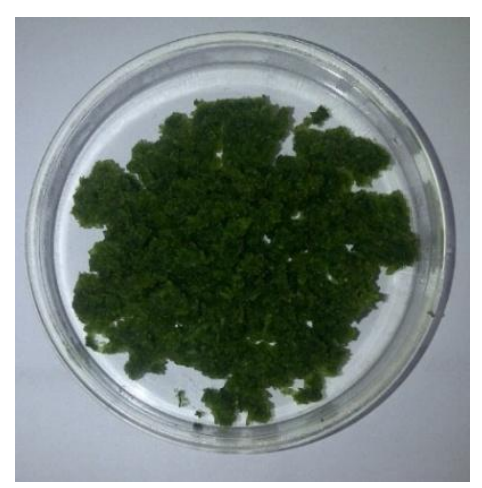

Figure 1. Raw Seaweed

Table 1. Composition of Raw Seaweed in $100 \mathrm{~g}$ samples

\begin{tabular}{lc}
\hline Composition & Raw seaweed \\
\hline Energy(Kcal) & 162 \\
Protein (g) & 0.8 \\
Lipid (g) & 0.5 \\
Carbohydrate (g) & 38.6 \\
Moisture (g) & 55.0 \\
Ash (g) & 5.1 \\
lodine (mg) & 0,52 \\
Calcium (mg) & 435 \\
Iron (mg) & 49.7 \\
Sodium (mg) & 13.0 \\
\hline
\end{tabular}


From fresh seaweed, the calculated dried powder of seaweeds in dry basis contains iodine of $1,15 \mathrm{mg} / 100 \mathrm{~g}$ or $0,29 \mathrm{mg} / 25 \mathrm{~g}$ dry basis, iron $110,4 \mathrm{mg} / 100 \mathrm{~g}$ or $27,6 \mathrm{mg} / 25 \mathrm{~g}$ dry basis and calcium of $966,6 \mathrm{mg} / 100 \mathrm{~g}$ or $241.6 \mathrm{mg} / 25 \mathrm{~g}$ dry basis. Dextrin in this formula to improve the stability of nutrients in seaweed, improve its texture and the salty fish extract to improve acceptability due to special flavor and taste the product. This picture below that shown the pictures of product of seaweed in this study. In picture 2, shown the product made from dry seaweed having dark green powder caused hot temperature of the oven. The dried seaweed made difficult to mix with dextrin making the seaweed sheet not smooth powder. While in the picture 3 shown the product that made from raw seaweed is looked fresh green; the dextrin mixed well with the seaweed.

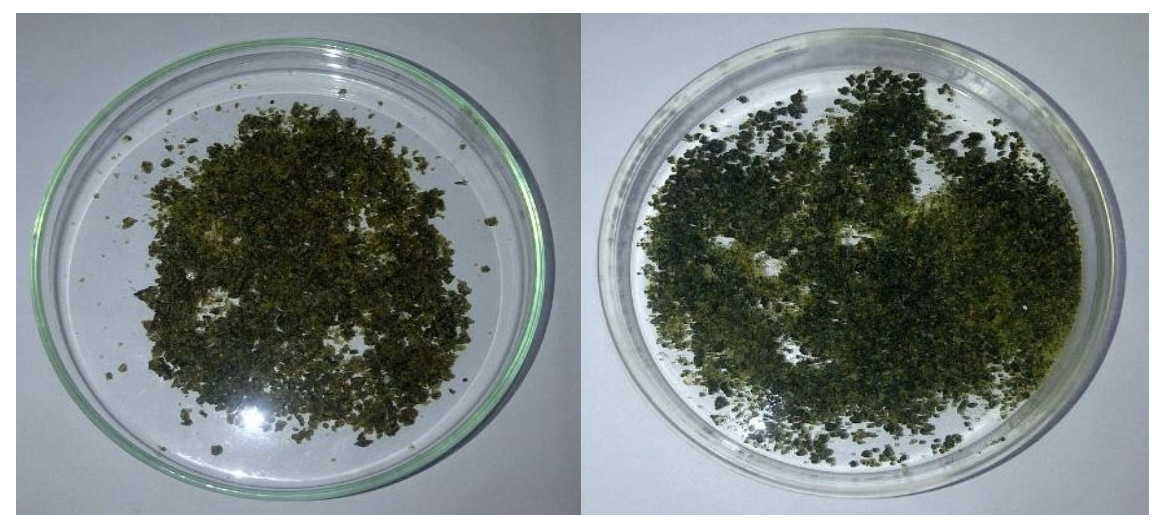

a. b

Figure 2. Products (a) made from dryseaweed (b) Product made direct from raw seaweed

Table 2. The Calculated Composition of Seaweed Supplementin $25 \mathrm{~g} / \mathrm{serving}$

\begin{tabular}{lc}
\hline Composition & Food supplements \\
\hline Energy (Kcal) & 76.28 \\
Protein (g) & 0.32 \\
Lipid (g) & 0.2 \\
Carbohydrate (g) & 18.3 \\
Moisture (g) & 0.1 \\
Ash (g) & 5.1 \\
lodine (mg) & 0.21 \\
Calcium (mg) & 174 \\
Iron (mg) & 17.8 \\
Sodium (mg) & 5.2 \\
\hline
\end{tabular}

Table 2 showed the calculated composition of seaweed product. It is showed that the composition nutrient of this product had high carbohydrate and micro nutrient but low in protein and lipid. The increase in carbohydrate content of this product is due to addition of dextrin. While sodium content increase, since the product is added by salty fish extract. The micronutrient compositions of seaweed supplements were iron $17,8 \mathrm{mg} / 25 \mathrm{~g}$ dry basis, iodine $0,21 \mathrm{mg} / 25 \mathrm{~g}$ dary basis and calcium of $174 \mathrm{mg} / 25 \mathrm{~g}$ dry basis. This recovered micronutrients 
compared to Table 1 were lower than calculated figures. This may be due to the effect of addition of dextrin.

Based on Recommended Dietary Intake (RDI), the compare of children's daily requirement of micro nutrient with the seaweed product were $25 \mathrm{~g}$ of this product could be supply the intake of children'srequirement for $23 \%$ in iodine, for $100 \%$ in iron and for $22-35 \%$ in calcium.

The formula of this supplement was made from raw seaweed and results in more attractive supplementtherefore the nutrient content of product was calculated. Applied technology of this supplement can be adapted in household level (Figure 3).

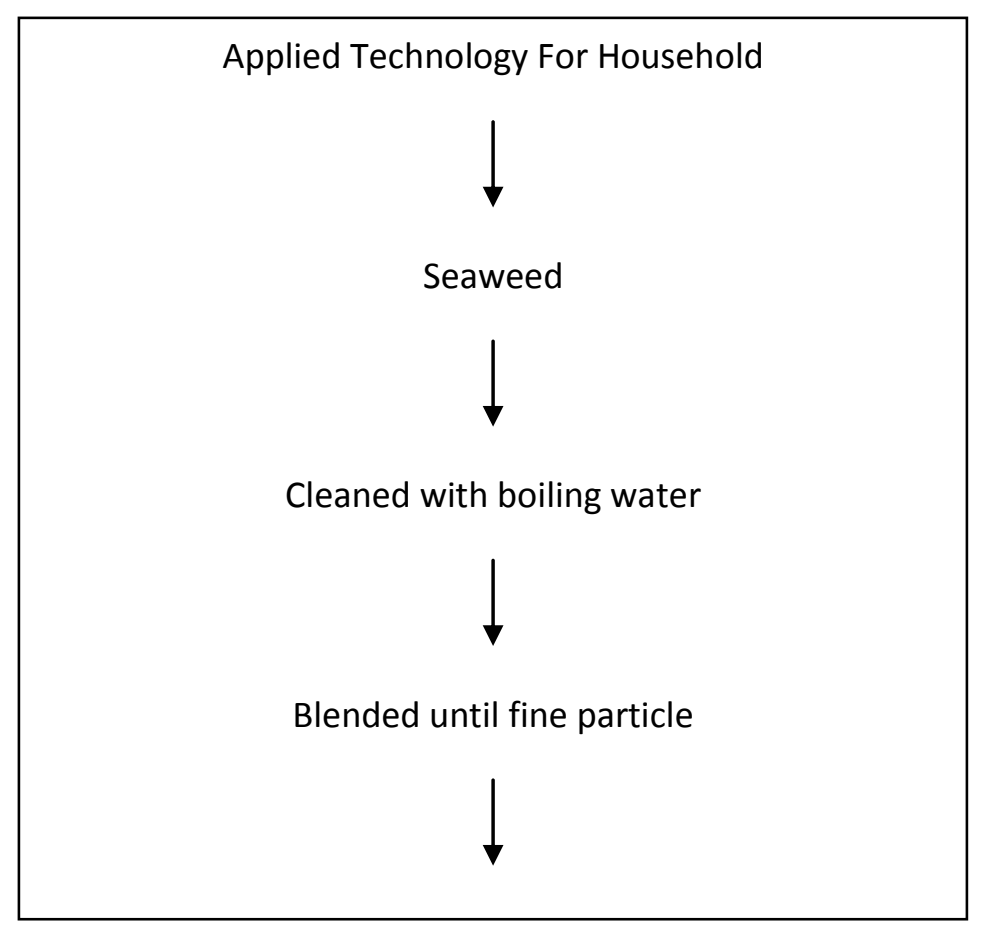

Figure 3. Applied Technology of Household Level Adapted

\section{CONCLUSION}

The dried seaweed formula can be useful in fortification of rice at point of consumption or in-house fortification.

The seaweed product developed in this study can be prepared in household level. The seaweed product could be used as food supplement or fortification formula content micronutrients especially for children. Further research could be prepared to measure effectively of the supplement.

\section{ACKNOWLEDGEMENTS}

The authors wish to thank Prof. Komari for editing the paper. 


\section{REFERENCES}

Hidayati L, Hadi H, Kumara A. 2010. Kekurangan Energi Dan Zat Gizi Merupakan Faktor Risoko Kejadian Stunted Pada Anak Usia 1-3 Tahun Yang Tinggal Di Wilayah Kumuh Perkotaan Surakarta.Jurnal Kesehatan, ISSN 1979-7621, Vol. 3(1): 89-104

National Institution for Health Researches \& Development (NIHRD), Basic Research on Health, 2008

Rasyid A. 2004. BeberapaCatatanTentang Agar.Oseana.VolXXIX(2):1-7

Komari, Lamid A, Yuniati H, Hermana. 1997. Bioteknologirumputlautuntukproduksi antiaterogenesis. Pros. Sem. Tek. Pangan 1997: 88-94.

Lamid A, Yuniati H, Affandi E. 1999. Stabilitation of Seaweed Bioactive Components. Report's Research of Health Department in Indonesia.

ASEANFOODS. 2011. The Asean Manual of Food Analysis. Institute of Nutrition, Mahidol University.

Burri S, Tato I, Leonor M, Morais R. 2011. Functional Vegetable Based Sausages For Consumption By Children. Food And Nutritional Sciences. (2): 494-501.

Burtin P. 2006, Nutritional Value of Seaweed.Electronic Journal Environment Agriculture Food. $5(3): 6$

Dawezsky C, Schubert R, Jahreis G. 2007. Amino Acids, Fatty Acids and Dietary Fiberin Edible Seaweed Product. Food Chemistry. (103):891-899

Handayani T. 1996. Protein pada Rumput Laut. Oseana Journal. 31(4):23-30.

Horwitz W. 2005. Official Methods of Analysis of AOAC International.Maryland:AOAC International, 2005

Ortiz J, Romero N, Robert P, Araya J, Lopez-Hernandez J, Bozzo CE, Navarrete CE, Rios A. 2006. Dietary fiber, Amino Acids, Fatty Acids and Tocopherol Contents Of The Edible Seaweed UlvaLactulaAndDurvillaeaAntartica. Food Chemistry. (99):98-104

Siddique, MAM, Aktar M, MohdKhatib MA. 2013. Proximate chemical composition and amino acid profile of two red seaweeds (Hypneapannosa and Hypneamusciformis) collected from St. Martin's Island, Bangladesh. Journal of Fisheries Sciences.com 7(2): 178-186.

Teas J, Pino S, Chritchley A, Lewis E, Braverman. 2004. Variability of iodine content in Common Commercially Available Edible Seaweeds. Thyroid Journal, 2004.Vol.14(10):836-841. 